\title{
The Effect of Pulmonary Surfactant on the Airway Smooth Muscle After Lipopolysaccharide Exposure and its Mechanisms
}

\author{
J. TOPERCEROVA ${ }^{1}$, M. KOLOMAZNIK ${ }^{2}$, J. KOPINCOVA $^{1}$, Z. NOVA $^{1}$, A. URBANOVA ${ }^{2}$, \\ D. MOKRA ${ }^{1,2}$, J. MOKRY $^{2,3}$, A. CALKOVSKA ${ }^{1}$ \\ ${ }^{1}$ Department of Physiology, Jessenius Faculty of Medicine in Martin, Comenius University in \\ Bratislava, Martin, Slovak Republic, ${ }^{2}$ Division Respirology, Martin Biomedical Centre, Jessenius \\ Faculty of Medicine in Martin, Comenius University in Bratislava, Martin, Slovak Republic, \\ ${ }^{3}$ Department of Pharmacology, Jessenius Faculty of Medicine in Martin, Comenius University in \\ Bratislava, Martin, Slovak Republic
}

Received March 21, 2019

Accepted November 27, 2019

\begin{abstract}
Summary
Pulmonary surfactant has a relaxing effect on the airway smooth muscle (ASM), which suggests its role in the pathogenesis of respiratory diseases associated with hyperreactivity of the ASM, such as asthma and chronic obstructive pulmonary disease (COPD). The ASM tone may be directly or indirectly modified by bacterial wall component lipopolysaccharide (LPS). This study elucidated the effect of LPS on the ASM reactivity and the role of surfactant in this interaction. The experiments were performed using ASM of adult guinea pigs by in vitro method of tissue organ bath (ASM unexposed-healthy or exposed to LPS under in vitro conditions) and ASM of animals intraperitoneally injected with LPS at a dose $1 \mathrm{mg} / \mathrm{kg}$ of b.w. once a day during 4-day period. Variable response of LPS was controlled by cyclooxygenase inhibitor indomethacin and relaxing effect of exogenous surfactant was studied using leukotriene and histamine receptor antagonists. The exogenous surfactant has relaxing effect on the ASM, but does not reverse LPS-induced smooth muscle contraction. The results further indicate participation of prostanoids and potential involvement of leukotriene and histamine $\mathrm{H}_{1}$ receptors in the airway smooth muscle contraction during LPS exposure.
\end{abstract}

\section{Key words}

Pulmonary surfactant • Airways • Smooth muscle • Reactivity • Lipopolysaccharide

\section{Corresponding author}

A. Calkovska, Department of Physiology, Jessenius Faculty of Medicine in Martin, Comenius University in Bratislava,
Mala Hora 4C, SK-03601 Martin, Slovak Republic. E-mail: calkovska@jfmed.uniba.sk

\section{Introduction}

The respiratory system represents a large interface between the body and the external environment. It is permanently exposed to toxins and pathogens that are delivered by air or blood. Lipopolysaccharide (LPS) also named endotoxin can reach the respiratory system as the major component of the outer membrane of Gramnegative bacteria (Raetz et al. 1991). It is a macromolecule composed of lipid part with six hydrocarbon chains (so called lipid A) and hydrophilic polysaccharide part forming O-antigen. LPS binds to toll-like receptor (TLR) complex CD14/TLR4/MD-2 which is present on membranes of various cells (Xiang et al. 2010). It induces both pro-inflammatory and pro-oxidative pathways which are widely interrelated (Salvesen et al. 2010). In addition to the effect induced by binding to TLR4, LPS interferes directly with the surfactant film, fluidizes it and leads to its damage (Kolomaznik et al. 2018). The result is the damage of pulmonary tissue and alveolar-capillary membrane, influx and activation of neutrophils, protein leakage followed by respiratory failure as a part of acute respiratory distress syndrome (ARDS) (Nova et al. 2019). Therefore, local defense mechanisms including pulmonary surfactant synthesized and secreted by alveolar type II cells are of a great importance (LopezRodriguez and Pérez-Gil 2014). Surfactant is a surface 
active substance consisting mainly of phospholipids and SP-A, SP-B, SP-C and SP-D specific proteins (Kolomaznik et al. 2014). Its principal function is to reduce surface tension at the air-liquid interface and to prevent collapse of the alveoli and small airways at the end of exhalation (Leonenko et al. 2006, Kopincova et al. 2014). Moreover, pulmonary surfactant has an important role in airway physiology as it controls wall thickness and airway diameter. Airway instillation of surfactant ameliorated bronchoconstriction induced by allergen (Liu et al. 1996). Direct relaxing effect of surfactant on the airway smooth muscle in vitro was documented (Koetzler et al. 2006) indicating that potential inactivation of surfactant may play role in pathogenesis of diseases related to hyperreactivity of small airways such as asthma (Enhorning 2008). This effect is partially dependent on prostanoids synthesis (Koetzler et al. 2006) and is not mediated through ATP-dependent potassium channels and cAMP-regulated epithelial chloride channels known as cystic fibrosis transmembrane regulator (CFTR) chloride channels, or nitric oxide (Calkovska et al. 2015).

Leukotrienes, as potent lipid mediators in inflammation (Peters-Golden et al. 2005), similarly as histamine receptor involvement may be the minor suppressors of surfactant relaxing ability and their antagonists widely used for the treatment of allergic rhinitis or bronchial asthma suggest their participation in relaxing mechanisms of surfactant (Gelfand 2002). The action of endotoxin in the respiratory system is complex. In the epithelial cells, it induces the formation of antimicrobial peptides (AMPs) which in addition to antimicrobial properties act as inflammatory mediators (Scott et al. 2011) and increases the permeability of endothelial cells (Zhou et al. 2018). As for the airway smooth muscle, the information on direct or indirect effects of endotoxin on airway responsiveness are inconsistent. Yamawaki et al. (1990) reported on LPS-induced hyperresponsiveness of the airway smooth muscle of the guinea pig, by reducing the ability of the respiratory epithelium to produce a relaxation factor (EpDRF). In contrary, in other study LPS led to the hyporeactivity of guinea pig airways by stimulating the release of EpDRF (Johnston et al. 2004). Later, airway hyperreactivity after LPS challenge was attributed to neuropeptide (Marek et al. 2008). On isolated guinea-pig tracheal strips it was possible to induce inflammation, however, an increase in airway responsiveness could not be demonstrated.

Based on literary evidence, the aim of the study is to investigate the effect of endotoxin on the airway smooth muscle. Although literary data differ in this respect, we aimed to prove the hypothesis that LPS leads to hyperreactivity. Because potential inactivation of pulmonary surfactant may play role in pathogenesis of diseases related to hyperreactivity of small airways and surfactant is known to have a relaxing effect on the airway smooth muscle, another goal of the study is to verify the hypothesis that eventual hyperreactivity will be blocked by the surfactant. An important part of the study is to detect the mechanisms involved in relaxing effect of surfactant on the airway smooth muscle.

\section{Materials and Methods}

The experimental protocol is in agreement with ethical guidelines for protection of animals used for scientific purpose and was approved by the local Ethics Committee of Jessenius Faculty of Medicine in Martin No. EK 46/2018, Comenius University in Bratislava and by the State Veterinary and Food Administration of the Slovak Republic. Ninety adult male guinea pigs (TRIK strain) of body weight (b.w.) 300-350 g were used. The animals were obtained from Department of Toxicology and Laboratory Animal Breeding Station at Dobra Voda in Slovakia and were kept in faculty animal house during 5 days long quarantine at $12 \mathrm{~h}$ light-dark cycle, with food and water at their disposal ad libitum.

The experiments were performed by method of tissue organ baths using tracheal and lung tissue strips of two main groups of animals: 1) animals intraperitoneally (i.p.) injected with lipopolysaccharide (LPS) from Escherichia coli O55:B5 (Sigma-Aldrich, St. Louis, MO, USA) at a dose $1 \mathrm{mg} / \mathrm{kg}$ b.w. during 4 days, once a day (group "LPS in vivo"); 1a) animals i.p. injected with $1 \mathrm{ml}$ of saline $(0.9 \% \mathrm{NaCl})$ at the same schedule (control group "Saline in vivo"); 2) healthy animals with LPS exposure in vitro at a dose 0.2 and $2.0 \mathrm{mg} / \mathrm{ml}$ in a single organ bath chamber (group "LPS in vitro"), higher dose of LPS $(2 \mathrm{mg} / \mathrm{ml})$ was more effective and therefore it is further referred in text as "LPS in vitro"; 2a) healthy animals with no exposure (group "healthy control or vehiculum, when sterile saline in vitro was added"). The effect of surfactant was tested by adding exogenous modified porcine surfactant (Curosurf, Chiesi Farmaceutici, Italy) at a dose of $1 \mathrm{mg} / \mathrm{ml}$ in organ bath (in vitro). Since leukotriene and histamine receptor involvement are related to respiratory diseases associated with an allergic responses (Jones et al. 1995) and in order to investigate mechanisms of relaxing 
effect of surfactant on the airway smooth muscle each group was divided into three subgroups exposed to leukotriene antagonist montelukast sodium, histamine receptors antagonists $\mathrm{H}_{1}$ mepyramine maleate and $\mathrm{H}_{2}$ cimetidine hydrochloride, in cumulative doses $\left(10^{-8}-10^{-4} \mathrm{~mol} / \mathrm{l}\right)$ (Sigma-Aldrich, St. Louis, MO, USA).

The animals were overdosed by i.p. administration of tiletamine and zolazepam (Zoletil, Virbac, France) at the dose of $1.25 \mathrm{mg} / \mathrm{kg}$ b.w. combined with xylazine (Xylariem, Riemser, Germany) at the dose of $2.0 \mathrm{mg} / \mathrm{kg}$ b.w.

Total and differential leukocyte count in blood and bronchoalveolar lavage fluid

To evaluate the effect of intraperitoneal LPS administration, immediately after an overdose of animals with anesthetics the blood was collected by heart puncture and processed. Bronchoalveolar lavage (BAL) was performed twice from the right lungs with sterile saline $(0.9 \% \mathrm{NaCl})$ heated to $37^{\circ} \mathrm{C}$ at the dose of $10 \mathrm{ml} / \mathrm{kg}$ b.w. The white blood cell count in blood and BAL fluid was evaluated by an automatic hematology analyzer (Sysmex) and expressed in absolute values $\left(\right.$ cell $\left.\times 10^{9} / 1\right)$.

\section{Preparation of tracheal and lung tissue strips}

Tracheal and lung tissue was removed. One or two tracheal strips were made by cutting the trachea on the both sides, in order not to damage the muscle area, into $15 \mathrm{~mm}$ long parts in the longitudinal axis. Tracheal strips were purified from surrounding tissues. One or two lung tissue strips $(2 \mathrm{~mm} \times 2 \mathrm{~mm} \times 15 \mathrm{~mm})$ containing smooth bronchial muscle were cut from the upper lobe of the left lung lobe. In vitro measurement of the airway reactivity was carried out in the eight channel modular tissue bath system for smooth muscle investigations (Experimetria, Hungary).

\section{In vitro airway reactivity assessment}

The tissue strips were immediately mounted between two hooks and placed into the $20 \mathrm{ml}$ tissue bath chambers filled with Krebs-Henseleit solution $(\mathrm{NaCl}$ $110.0 \mathrm{mmol} / \mathrm{l}, \quad \mathrm{KCl} \quad 4.8 \mathrm{mmol} / 1, \mathrm{CaCl}_{2} 2.35 \mathrm{mmol} / \mathrm{l}$, $\mathrm{Mg}_{2} \mathrm{SO}_{4} \quad 1.2 \mathrm{mmol} / 1, \quad \mathrm{KH}_{2} \mathrm{PO}_{4} \quad 1.2 \mathrm{mmol} / 1, \quad \mathrm{NaHCO}_{3}$ $25.0 \mathrm{mmol} / 1$, glucose $10.0 \mathrm{mmol} / \mathrm{l}$ in distilled water). Solution warming was provided by thermoregulation unit, maintained at $37 \pm 1{ }^{\circ} \mathrm{C}$ and continuously gassed with pneumoxid (mixture of $95 \% \mathrm{O}_{2}$ and $5 \% \mathrm{CO}_{2}$, in order to maintain $\mathrm{pH}$ value at $7.5 \pm 0.1$ ). The contractile force was transmitted to a transducer and an amplifier. Changes in isometric tension were measured and recorded with online computer software SPEL Advanced ISO v3.2 (Experimetria, Hungary). To allow adaptation (loading phase), the tissue strips were adjusted to $4 \mathrm{~g}$ of tension (30 min). Afterwards, tension was reduced to $2 \mathrm{~g}$ as a baseline value (30 min; adaptation phase). During both phases, strips were pre-washed every $10 \mathrm{~min}$ with KrebsHenseleit solution. Tracheal and lung tissue strips were precontracted with methacholine chloride $(1 \mu \mathrm{M})$ and exposed to different concentrations of tested substances. Methacholine was repeatedly applied at the end of the measurement to compare reactivity of tissue before and after the procedure. The contractile response of the smooth muscle was then evaluated as a change of the contraction force of methacholine-precontracted tracheal and lung tissue strip after incubation with different substances for $5 \mathrm{~min}$ for methacholine chloride, montelukast sodium, mepyramine maleate and cimetidine chloride and $15 \mathrm{~min}$ for Curosurf and LPS in vitro exposition. Tracheal and lung tissue reactivity data are expressed in grams ( $\mathrm{g}$ ) of the smooth muscle tension (Mokry et al. 2006). The measurements were done with 4-8 tissue samples in each group.

\section{Statistical analyses}

Statistical analysis was performed by using computer programme GraphPad Prism version 6.04 (GraphPad Software, USA). The One-way ANOVA and Kruskal-Wallis test were used in order to determine differences between the groups. Data are shown as mean \pm standard error (SEM). P-values less than 0.05 were considered as statistically significant $(\mathrm{P}<0.05)$.

\section{Results}

Systemic response induced by intraperitoneal LPS administration

LPS administration significantly increased the total white blood cell (WBC) count as well as eosinophil, monocyte and lymphocyte count in blood in comparison with control group receiving saline $(\mathrm{P}<0.05-0.0001)$. The rise of neutrophil and basophil count was not significant (Table 1). There was a significant reduction of neutrophil count $(\mathrm{P}<0.05)$, a trend to the decrease in total $\mathrm{WBC}$, lymphocyte and eosinophil count in BALF and the increase in monocyte count in "LPS in vivo" group in comparison with "Saline in vivo" group. The number of basophils was not detectable (Table 1). 
Table 1. The amount of total white blood cells and their classes (cell $\left.\times 10^{9} / \mathrm{l}\right)$ in blood and bronchoalveolar lavage fluid (BALF) obtained from animals with intraperitoneal LPS administration at the dose of $1 \mathrm{mg} / \mathrm{kg}$ of b.w. (LPS in vivo; $\mathrm{n=12}$ ) and sterile saline (1 ml) (Saline in vivo; $\mathrm{n}=7$ ).

\begin{tabular}{|c|c|c|c|c|c|c|c|c|c|c|c|c|}
\hline & \multicolumn{2}{|c|}{ TOTAL WBC } & \multicolumn{2}{|c|}{ NEUTROPHILS } & \multicolumn{2}{|c|}{ LYMPHOCYTES } & \multicolumn{2}{|c|}{ MONOCYTES } & \multicolumn{2}{|c|}{ EOSINOPHILS } & \multicolumn{2}{|c|}{ BASOPHILS } \\
\hline & Blood & $B A L F$ & Blood & $B A L F$ & Blood & $B A L F$ & Blood & $B A L F$ & Blood & $B A L F$ & Blood & $B A L F$ \\
\hline Saline & 1.576 & 0.673 & 0.636 & 0.425 & 0.824 & 0.154 & 0.110 & 0.080 & 0.004 & 0.014 & 0.001 & 0.000 \\
\hline in vivo & \pm 0.247 & \pm 0.063 & \pm 0.089 & \pm 0.036 & \pm 0.151 & \pm 0.026 & \pm 0.022 & \pm 0.008 & \pm 0.002 & \pm 0.004 & \pm 0.001 & \pm 0.000 \\
\hline$L P S$ & $2.732^{\mathrm{b}}$ & 0.544 & 1.083 & $0.328^{\mathrm{a}}$ & $1.277^{\mathrm{a}}$ & 0.098 & $0.313^{\mathrm{b}}$ & 0.108 & $0.053^{\mathrm{c}}$ & 0.010 & 0.006 & 0.000 \\
\hline in vivo & \pm 0.341 & \pm 0.057 & \pm 0.258 & \pm 0.042 & \pm 0.112 & \pm 0.017 & \pm 0.041 & \pm 0.015 & \pm 0.009 & \pm 0.002 & \pm 0.002 & \pm 0.000 \\
\hline
\end{tabular}

Data are shown as mean \pm standard error $(\mathrm{SEM})$. ${ }^{\mathrm{a}}$ Significant difference $(P<0.05),{ }^{\mathrm{b}}$ significant difference $(\mathrm{P}<0.01)$ and ${ }^{\mathrm{c}}$ significant difference $(P<0.0001)$ in comparison with Saline in vivo.

LPS- and surfactant-induced changes in airway smooth muscle responsiveness

Tracheal smooth muscle (TSM) reactivity of the "healthy group" after exposure to LPS to organ bath at the dose of $0.2 \mathrm{mg} / \mathrm{ml}$ was not significantly changed (Fig. 1A). Exposition of TMS to LPS at $2 \mathrm{mg} / \mathrm{ml}$ for five minutes led to moderate increase in contractile response in comparison with the lower dose of LPS $(0.2 \mathrm{mg} / \mathrm{ml})$. In lungs, the contractile response to final methacholine exposure was significantly higher than the contractile response to LPS (Fig. 1B). After exposition of TSM to LPS the strips were exposed to exogenous surfactant. This caused significant decrease in reactivity in comparison to LPS only. However, in response to final (second) dose of methacholine there was slight increase in reactivity in comparison to initial (first) application of methacholine. Significant difference in responses occurred in ASM reaction between administration of LPS and final methacholine (Fig. 1A). In the group with ASM exposed to LPS for prolonged period $15 \mathrm{~min}$ and followed by surfactant application, tracheal contractility significantly decreased in response to LPS, likewise in response to final methacholine. Lung tissue strips of animals in all groups responded to LPS exposure with reduction of contractility at comparable degree. In contrary, there was a significant increase in reactivity of ASM after final methacholine in comparison to LPS response occurring in all groups (Fig. 1B).
$1 A$

\section{Trachea}

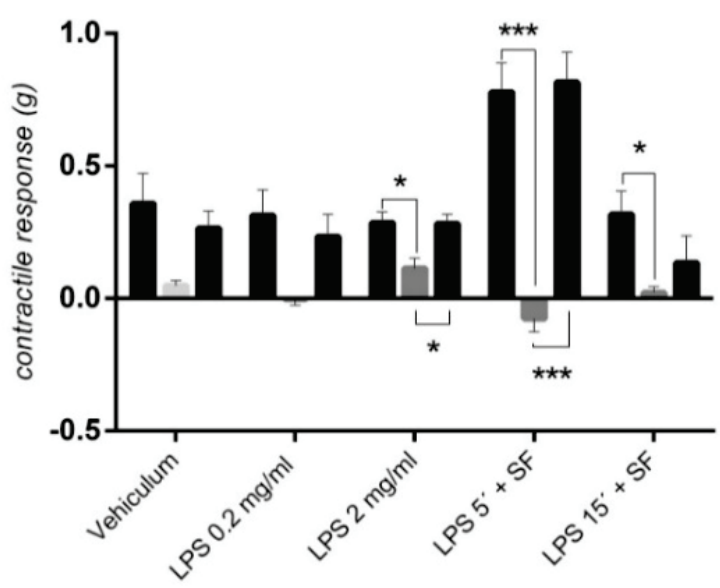

$1 B$

\section{Lungs}

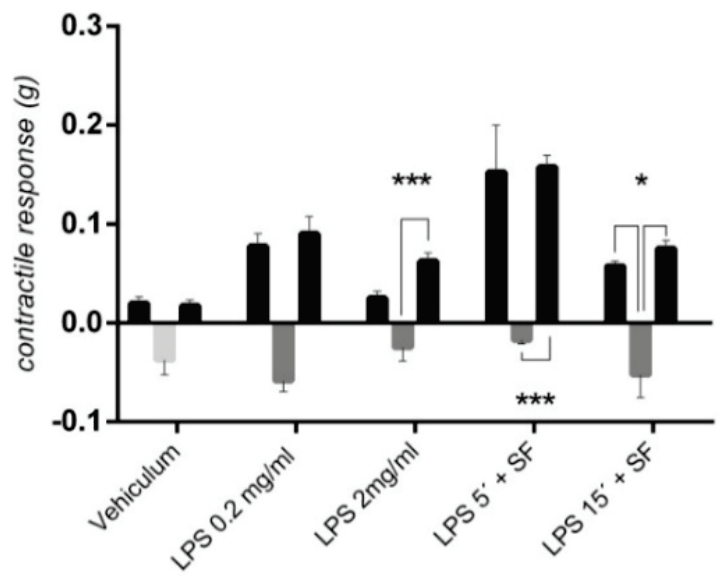

Vehiculum

LPS in vitro

Fig. 1. Responses of tracheal and lung tissue strips of healthy animals $(n=8)$ under in vitro conditions after administration of vehicle, LPS and exogenous surfactant ( $1 \mathrm{mg}$ of phospholipids/ml) application in vitro (data are expressed in $\mathrm{g} / 100 \mathrm{mg}$ of tissue). Methacholine at a concentration of $10^{-6} \mathrm{~mol} / \mathrm{l}$ was used to compare contractile responses. Values are expressed as mean $\pm S E M$. For statistical comparisons in trachea (A): LPS in vitro group: LPS in vitro vs. final methacholine (FM) ${ }^{*} \mathrm{P}<0.05$. LPS $5^{\prime}+$ SF group: LPS in vitro vs. $\mathrm{FM}^{* * *} \mathrm{P}<0.001$. Statistical comparison in lungs (B): LPS in vitro group: LPS in vitro vs. FM ${ }^{* * *} \mathrm{P}<0.001$. LPS $5^{\prime}+\mathrm{SF}$ group: LPS in vitro vs. FM ${ }^{* * *} \mathrm{P}<0.001$. LPS $15^{\prime}+\mathrm{SF}$ group: LPS in vitro vs. FM ${ }^{*} \mathrm{P}<0.05$. 
In order to clarify tracheal and lung responsiveness to lipopolysaccharide, we eliminated the bronchodilatory effect of prostaglandins produced in both tracheal and bronchial tissue strips with cyclooxygenase inhibitor indomethacin at a concentration of $10^{-5} \mathrm{~mol} / 1$. We compared responses of ASM of two groups of healthy animals with or without using indomethacin (Fig. 2). No change in contractile response between initial and final methacholine was seen after exposure of tracheal smooth muscle to LPS without indomethacin. TSM of healthy animals exposed to LPS after indomethacin and then to methacholine responded with enhanced muscle tone. Subsequent administration of exogenous surfactant led to reduction in contractility, clearly visible after final methacholine administration (Fig. 2A). Significant reduction in TSM reactivity occurred in the group exposed to LPS and indomethacin in comparison to group with LPS without indomethacin. Final methacholine after incubation of TSM with indomethacin, LPS and surfactant exposure led to significant decrease in contractile responses of tracheal tissue strips (Fig. 2A). In lung tissue application of indomethacin reduced contractility not only within LPS but also in surfactant response. This effect was present also in group without administration of indomethacin, but to a lesser extent (Fig. 2B).

\section{$2 A$}

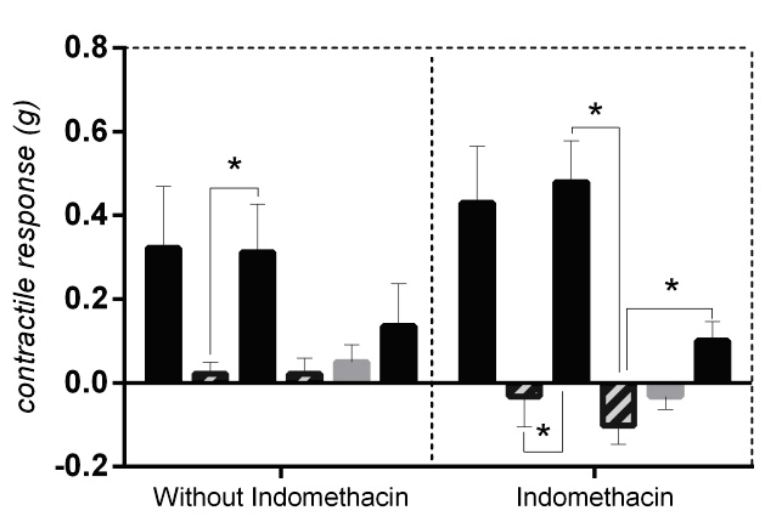

2B

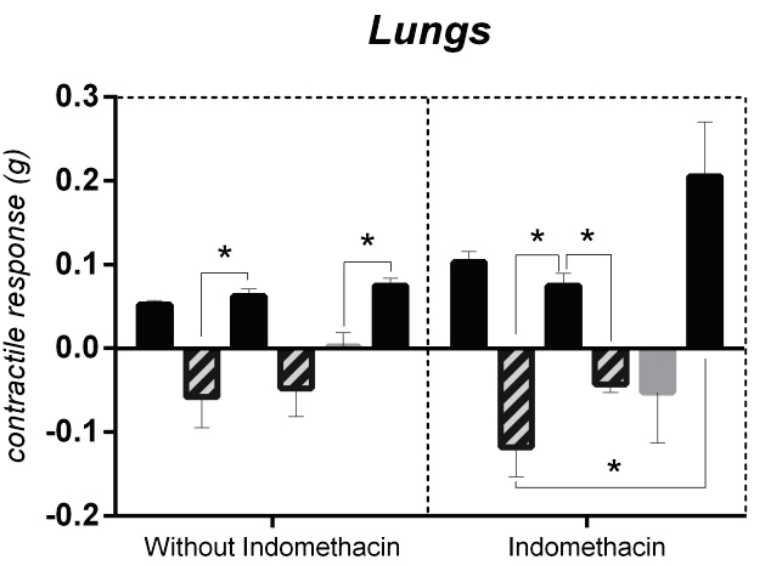

Methacholine

Fig. 2. Responses of tracheal and lung tissue strips of healthy animals $(n=4)$ under in vitro conditions without and with Indomethacin $\left(10^{-5} \mathrm{~mol} / \mathrm{l}\right)$, administered before LPS $(2 \mathrm{mg} / \mathrm{ml})$ and exogenous surfactant $(1 \mathrm{mg}$ of phospholipids/ml) application in vitro (data are expressed in $\mathrm{g} / 100 \mathrm{mg}$ of tissue). Methacholine at a concentration of $10^{-6} \mathrm{~mol} / \mathrm{l}$ was used to compare contractile responses. Values are expressed as mean \pm SEM. For statistical comparisons in trachea (A): (-) indomethacin: LPS in vitro vs. final methacholine (FM) ${ }^{*} \mathrm{P}<0.05$. (+) indomethacin: exogenous surfactant vs. $\mathrm{FM}{ }^{*} \mathrm{P}<0.05$, initial methacholine (IM) vs. LPS in vitro ${ }^{*} \mathrm{P}<0.05, \mathrm{LPS}$ in vitro vs. $\mathrm{FM}^{*} \mathrm{P}<0.05$. Statistical comparison in lungs (B): (-) indomethacin: LPS in vitro vs. FM ${ }^{*} \mathrm{P}<0.05$, exogenous surfactant vs. $\mathrm{FM}{ }^{*} \mathrm{P}<0.05$. $(+)$ indomethacin: LPS in vitro vs. FM ${ }^{*} \mathrm{P}<0.05$, IM vs. LPS in vitro ${ }^{*} \mathrm{P}<0.05$, LPS in vitro vs. FM ${ }^{*} \mathrm{P}<0.05$.

\section{Mechanisms of surfactant's relaxation}

Response of TSM to exogenous surfactant was in accordance with its previously observed relaxing effect. Contractility of TSM of healthy controls exposed to LPS in organ bath showed moderate increase after surfactant administration in comparison to "LPS in vivo" group (Fig. 3A).

As expected, the reactivity after final dose of methacholine was reduced. In the group of "healthy controls" as well as in "Saline in vivo" and "LPS in vivo" group surfactant had direct relaxing effect on ASM. Significant reduction in contractile responses between initial and final methacholine administration was present only in the group of "healthy controls". In the "LPS in vivo" animals response to final methacholine administration remained unchanged. Relaxant response of lung tissue to surfactant was more pronounced than in tracheal tissue strips. ASM of healthy animals with no LPS exposure and animals pre-treated with LPS in vivo showed significantly reduced contractility in comparison to ASM of healthy animals exposed to LPS in vitro. Response to final methacholine dose in comparison to initial methacholine exposure remained almost unchanged in all groups except the group "Saline in vivo" (Fig. 3B). 
$3 A$

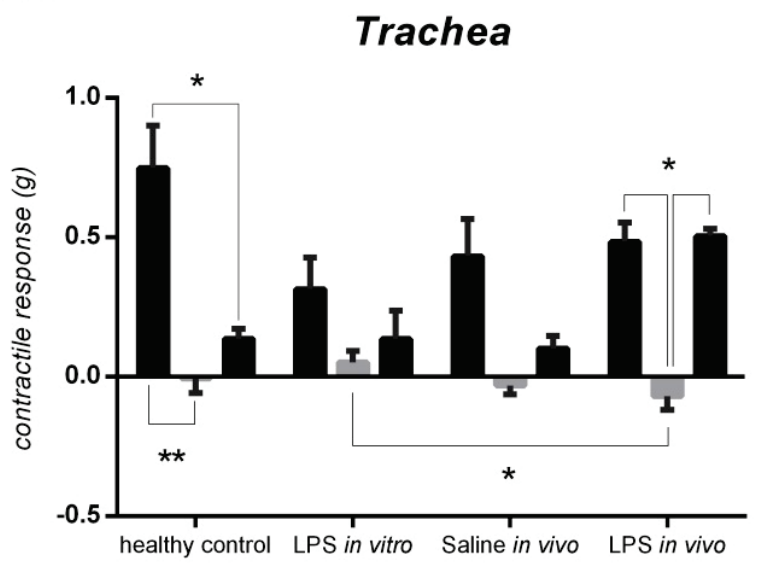

$3 B$

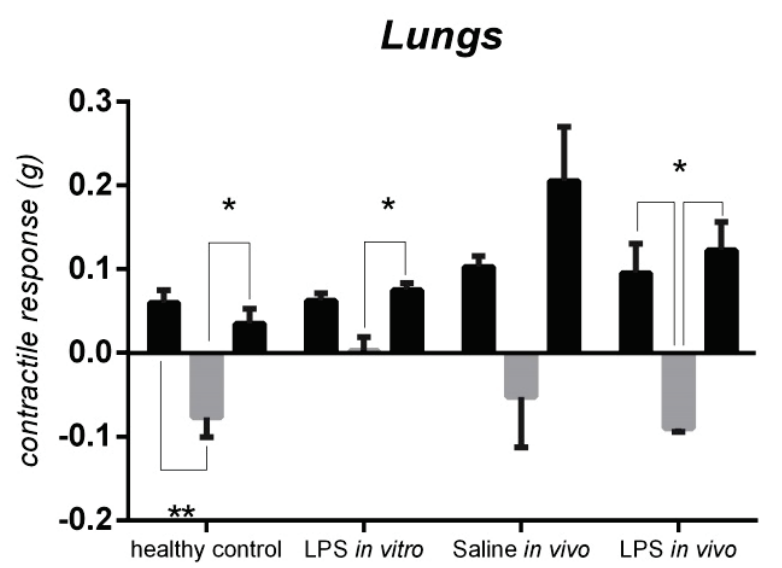

Methacholine

Surfactant

Fig. 3. Responses of tracheal and lung tissue strips $(n=4-8)$ under in vitro conditions in response to exogenous surfactant ( $1 \mathrm{mg}$ of phospholipids $/ \mathrm{ml}$ ) (data are expressed in $\mathrm{g} / 100 \mathrm{mg}$ of tissue). Methacholine at a concentration of $10^{-6} \mathrm{~mol} / \mathrm{l}$ was used to compare contractile responses. Values are expressed as mean \pm SEM. For statistical comparisons in trachea (A): healthy group: initial methacholine (IM) vs. final methacholine (FM) ${ }^{*} \mathrm{P}<0.05$, IM vs. exogenous surfactant ${ }^{* *} \mathrm{P}<0.01$, LPS in vitro vs. LPS in vivo group: exogenous surfactant vs. exogenous surfactant ${ }^{*} \mathrm{P}<0.05$. LPS in vivo group: IM vs. exogenous surfactant ${ }^{*} \mathrm{P}<0.05$, exogenous surfactant vs. $F M^{*} P<0.05$. Statistical comparison in lungs (B): healthy group: exogenous surfactant vs. $F M^{*} P<0.05$, IM vs. exogenous surfactant ${ }^{* *} \mathrm{P}<0.01$. LPS in vitro group: exogenous surfactant vs. $\mathrm{FM}{ }^{*} \mathrm{P}<0.05$. LPS in vivo group: IM vs. exogenous surfactant ${ }^{*} \mathrm{P}<0.05$, exogenous surfactant vs. $\mathrm{FM}{ }^{*} \mathrm{P}<0.05$.

The role of leukotriene and histamine receptor antagonists in mechanisms of surfactant relaxing effect

In order to elucidate the mechanisms of surfactant relaxing effect we tested the influence of pharmacological agents inhibiting leukotriene and histamine receptors, as they may potentiate relaxing effect of pulmonary surfactant. Montelukast sodium is known to reverse bronchoconstriction in smooth muscle of small airways by blockade of leukotrienes receptors and it was proven by decrease in contractile responses of tracheal smooth muscle between initial and final methacholine exposure in healthy group significantly and LPS in vivo pretreated group (Fig. 4A). Lung tissue strip containing bronchial smooth muscle responded by relaxation. Reactivity of lung tissue after final methacholine administration did not significantly decrease which corresponds to the reactivity of TSM. Similar response was observed after incubation of TSM with mepyramine maleate as $\mathrm{H}_{1}$ histamine receptor antagonist. There was significant decrease in contractile responses between initial and final methacholine dose in all three investigated groups (Fig. 4C). Cimetidine hydrochloride, a $\mathrm{H}_{2}$ histamine receptors antagonist, did not reduce contractility of tracheal or lung tissue strips (Fig. 4E, F).

\section{Discussion}

Lipopolysaccharide (LPS) is a potent proinflammatory cell wall component of Gram-negative bacteria (Weg et al. 1995, Kolomaznik et al. 2017). In the lower airways, bacterial lipopolysaccharide can interact with alveolar cells and pulmonary surfactant (Chaby et al. 2005), and may provoke LPS-induced airway hyperresponsiveness (Schwartz et al. 2001). Up to now, there is no consensus on direct or indirect effect of LPS on the airway smooth muscle reactivity (Yamawaki et al. 1990, Johnston et al. 2004, Marek et al. 2008). The reactivity of airway smooth muscle ASM in our study was investigated after LPS exposure in vivo (1 mg/kg b.w. for 4 days given intraperitoneally to guinea pigs) and in vitro (to organ bath). Single exposure of tracheal strip and lung tissue strip containing bronchial smooth muscle to LPS at a dose of $2 \mathrm{mg} / \mathrm{ml}$ into organ bath chamber induced ASM contraction. It is in accordance with Yamawaki et al. (1990) who associated LPS-induced airway hyperreactivity with reduced ability of respiratory epithelium to produce epithelium-derived relaxant factor (EpDRF). This effect was in contrast with the group in which LPS was added to organ bath for 5-minute-long exposure before exogenous surfactant administration at a dose of $1 \mathrm{mg} / \mathrm{ml}$. ASM tone decreased showing 
tendency to hyporeactivity. After surfactant administration the reactivity of ASM moderately increased. Similar effect was reported by Johnston et al. (2004) when LPS-treatment in vivo reduced airway smooth muscle contractility. Since contractile responses of ASM to LPS were variable in time we used smooth muscle precontracted with methacholine chloride. Airway reactivity of tracheal and lung tissue strips after LPS exposure in vitro and final methacholine exposure had tendency to increase suggesting that lipopolysaccharide leads to hyperreactivity.

\section{$4 A$}

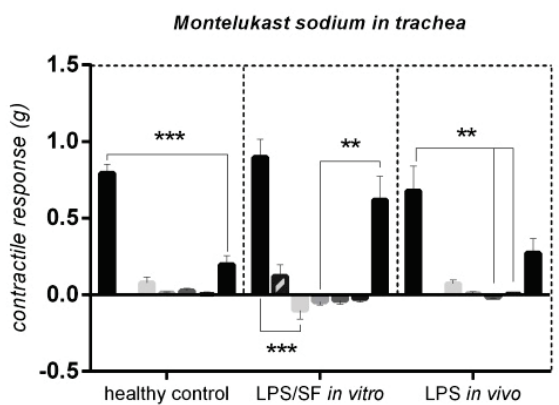

Methacholine

LPS in vitro

4C

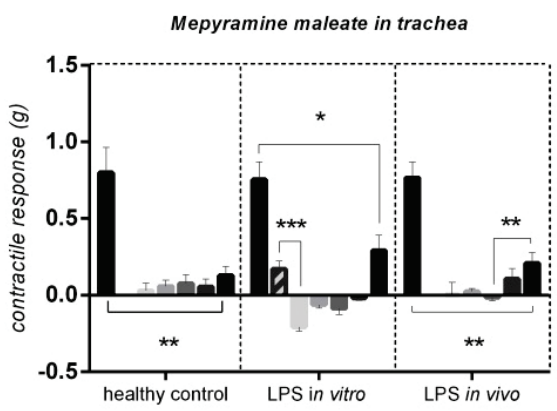

4E

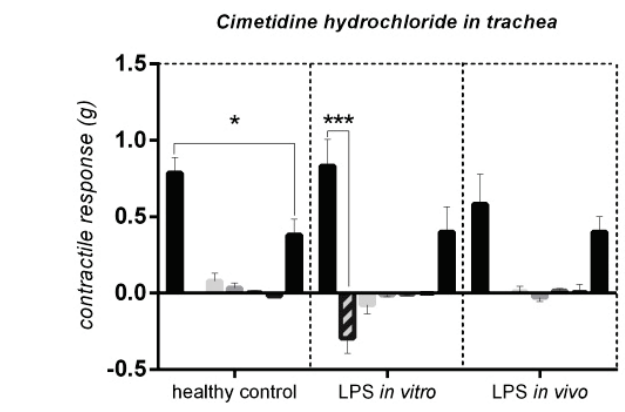

4B

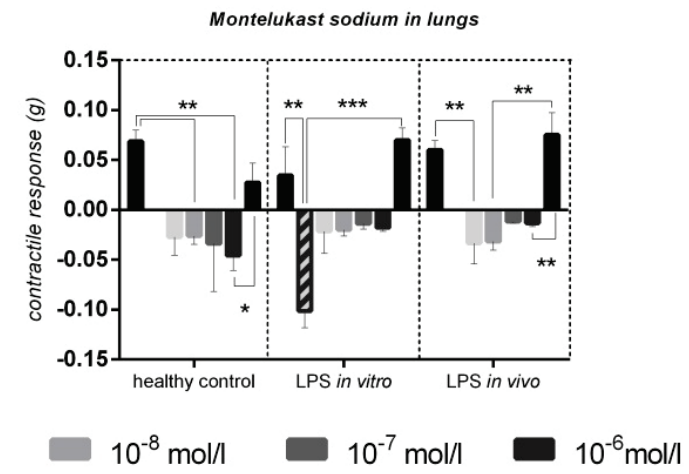

4D

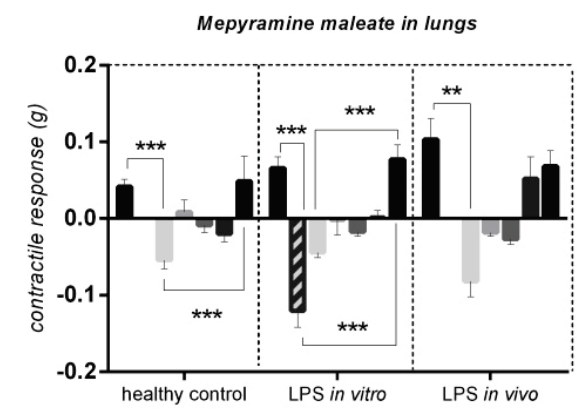

$4 F$

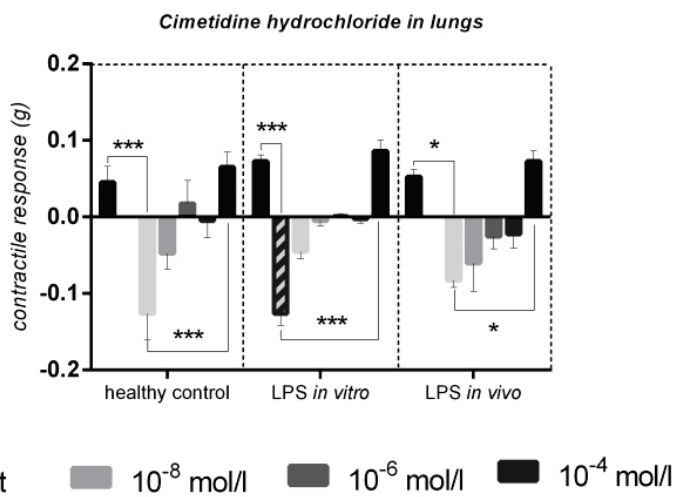

Fig. 4. Responses of tracheal $(\mathbf{A}, \mathbf{C}, \mathbf{E})$ and lung tissue strips $(\mathbf{B}, \mathbf{D}, \mathbf{F})(\mathrm{n}=4-7)$ under in vitro conditions in response to exogenous surfactant $(1 \mathrm{mg}$ of phospholipids $/ \mathrm{ml})$ in combination with leukotriene receptor antagonist montelukast sodium $\left(10^{-8}-10^{-6} \mathrm{~mol} / \mathrm{l}\right)$ and histamine receptor antagonists $\mathrm{H}_{1}$ mepyramine maleate and $\mathrm{H}_{2}$ cimetidine hydrochloride $\left(10^{-8}-10^{-4} \mathrm{~mol} / \mathrm{l}\right)$ (data are expressed in $\mathrm{g} / 100 \mathrm{mg}$ of tissue). Methacholine at a concentration of $10^{-6} \mathrm{~mol} / \mathrm{l}$ was used to compare contractile responses. Values are expressed as mean \pm SEM. For statistical comparisons in trachea (A): healthy group: initial methacholine (IM) vs. final methacholine (FM) ${ }^{* * *} \mathrm{P}<0.001$. Mepyramine maleate in trachea $(\mathbf{C})$ : healthy group: IM vs. $\mathrm{FM}{ }^{* *} \mathrm{P}<0.01$. LPS in vitro group: IM vs. $\mathrm{FM}{ }^{*} \mathrm{P}<0.05$. LPS in vivo group: IM vs. FM ${ }^{* *} \mathrm{P}<0.01$. Cimetidine hydrochloride in trachea (E): healthy group: IM vs. FM ${ }^{*} \mathrm{P}<0.05$. 
Prolonged 15-minute in vitro LPS exposure resulted in slight increase in contractile responses of tracheal smooth muscle but not in the lung tissue strip, probably due to the fact that endotoxin inhibits phenylephrine-induced vascular contractions (Beasley et al. 1990). In lung tissue strips, the response of bronchial smooth muscle can interfere with response of vascular smooth muscle which is present in the lungs in high extent. The conclusions therefore have to be preferentially based on tracheal tissue strip responses.

Smooth muscle tone is, beside other mediators, maintained by prostaglandins (Farmer et al. 1972) and indomethacin induces a dose-related tracheal relaxation by prostaglandin synthesis inhibition (Vane 1971). It is why we used indomethacin to control and understand the role of prostaglandins in the mechanisms of the LPS-induced contraction of the airway smooth muscle. Indomethacin-induced prostaglandin inhibition combined with in vitro LPS-exposure significantly reduced both tracheal and lung tissue reactivity. In the lungs, indomethacin has enabled stronger relaxation most probably due to large amount of vascular smooth muscle. Not only reactivity to LPS in vitro but also surfactant contractile response was suppressed. On the contrary, final methacholine dose in lung strip had opposite effect, most likely due to potential inhibition of cyclooxygenase by indomethacin (Ruan et al. 2010).

Potential inactivation of lung surfactant may play role in pathogenesis of diseases related to hyperresponsiveness as bronchial asthma and other diseases associated with the airway obstruction (Mokra and Calkovska 2017). Animal-derived surfactant preparations (e.g. Alveofact and Curosurf) routinely used to treat neonatal respiratory distress syndrome have been shown to directly relax airway smooth muscle (Calkovska et al. 2015). Exposure of ASM to single dose of exogenous surfactant ( $1 \mathrm{mg}$ of phospholipids/ml) supported its relaxing effect on the airway smooth muscle. Exposure of both tissue strips (tracheal and lung) of healthy and LPS-treated animals to surfactant finally confirmed a decrease in reactivity. Relaxation was stronger in lung tissue strips and was an expected result related to the fact that the smooth muscle of small bronchi is the primary site of surfactant relaxing effect. However, differences in response to final methacholine were present between groups. Reactivity of tracheal tissue of healthy animals after final methacholine was significantly reduced, whilst the response in LPS-treated group was unchanged in comparison with initial methacholine dose. It may be assumed that exogenous surfactant was unable to reduce muscle contractility if animals suffered from systemic inflammation induced by 4-day LPS instillation (LPS in vivo group). The difference in response to initial and final methacholine administration in lung tissue was almost unchanged. Final methacholine evoked slight increase in reactivity. This might be explained by presence of potential neurogenic inflammation induced by lipopolysaccharide as a consequence of hypothalamic neurokinin release as documented in rats i.p. instilled with $250 \mathrm{mg}$ of LPS per animal (De Laurentiis et al. 2003). Surfactant had no relaxing effect on tracheal and lung tissue strips after their previous LPS in vitro exposure. We suppose that lipopolysaccharide in organ bath chamber may create complexes with surfactant, incorporates into the surfactant lipid membrane and induces its dysfunction (Kolomaznik et al. 2018) which explains moderate increase in reactivity of ASM. In contrary, such a direct effect between LPS and surfactant was not present if the animals are treated i.p. with LPS.

Relaxing effect of surfactant was investigated even by using antagonists of leukotriene, $\mathrm{H}_{1}$ and $\mathrm{H}_{2}$ histamine receptors as potential mediators of surfactant relaxant activity. Inflammation, smooth muscle contraction and airway wall oedema are mediated by leukotrienes (Priyanka and Sathali 2012). Leukotriene receptor antagonist montelukast sodium is widely used for relief of symptoms in the treatment of asthma. Histamine $\mathrm{H}_{1}$-receptors mediate bronchoconstriction, vasoconstriction and edema formation. Pulmonary $\mathrm{H}_{2}$-receptors mediate bronchodilation (Parsons and Ganellin 2006) and vasoconstriction of pulmonary blood vessels (Marshall 1984). We have chosen histamine $\mathrm{H}_{1}$ and $\mathrm{H}_{2}$ receptor antagonists to antagonize the contractile response induced by LPS. Combination of surfactant relaxing effect and the releasing effect of receptor antagonists may show a direction how to intensify surfactant relaxing features in LPS-induced inflammation. The experiments clearly revealed that surfactant in combination with protective $\mathrm{H}_{1}$-receptor antagonist mepyramine maleate and leukotriene receptor antagonist montelukast sodium significantly reduced airway smooth muscle tone which indicates leukotriene and histamine $\mathrm{H}_{1}$ receptor involvement in contractile mechanisms of the airways exposed to LPS. The presence of cimetidine hydrochloride in organ bath did not confirmed significant participation of $\mathrm{H}_{2}$-receptors in these mechanisms. This is in line with other study when 
cimetidine-mediated receptor blockade did not affect bronchial reactivity to histamine in asthmatic subjects (Nogrady and Bevan 1981).

There is also a question in what degree can the key physiological feature of pulmonary surfactant, which is reduction of surface tension, be included in its relaxing effect. Theoretically, it may play a role in the lungs filled with the air when air-liquid interphase does exist but not in the liquid-filled organ chamber. According the study performed earlier by our group (Calkovska et al. 2015) surfactant relaxing effect has to be mediated by other mechanisms than those including nitric oxide, potassium or chloride channels. These results suggested that relaxing effect may be done through the specific receptors associated with prostaglandin release. This hypothesis was proven by using cyclooxygenase inhibitor indomethacin, primarily applied in order to control variable response of tracheal tissue exposed to LPS in vitro. In our study, indomethacin potentiated relaxation effect of surfactant, probably by reduction of prostaglandins (PGD2, PGF $_{2 \alpha}$ ) which may be released by tissue upon its incubation with LPS. Relaxant mechanism in vitro dependent on cyclooxygenase pathways and intact epithelium was also tested by Koetzler et al. (2006). They found out that indomethacin had a significant inhibitory effect on the bronchoconstrictor neurokinin substance P. In the same way, indomethacin intensified relaxing effect of surfactant, which indicates that bronchoconstrictory prostaglandins may participate in contractile mechanisms of the airway smooth muscle.

In conclusion, exogenous surfactant reduces airway smooth muscle (ASM) tone, however surfactant does not reverse LPS-induced ASM contraction. It is probably because of bronchoconstrictory prostaglandins released at exposure to LPS may interfere with relaxant activity of surfactant. The effect of exogenous surfactant may be potentiated by substances which suppress inflammation. The results further indicate potential involvement of leukotriene and histamine $\mathrm{H}_{1}$ receptors in the airway smooth muscle contraction during LPS exposure.

\section{Conflict of Interest}

There is no conflict of interest.

\section{Acknowledgements}

Study was supported by projects VEGA 1/0055/19, APVV-15-0075, APVV-17-0250 and GUK/33/2019. The authors thank Darina Kuliskova, Zuzana Remisova and Miroslav Hutko for technical assistance.

\section{References}

BEASLEY D, COHEN RA, LEVINSKY NG: Endotoxin inhibits contraction of vascular smooth muscle in vitro. Am J Physiol 258: H1187-H1192, 1990.

CALKOVSKA A, UHLIAROVA B, JOSKOVA M, FRANOVA S, KOLOMAZNIK M, CALKOVSKY V, SMOLAROVA S: Pulmonary surfactant in the airway physiology: a direct relaxing effect on the smooth muscle. Respir Physiol Neurobiol 209: 95-105, 2015.

DE LAURENTIIS A, CANDOLFI M, PISERA D, SEILICOVICH A: Effects of lipopolysaccharide on neurokinin A content and release in the hypothalamic-pituitary axis. Regul Pept 111: 91-95, 2003.

ENHORNING G: Surfactant in airway disease. Chest 133: 975-980, 2008.

FARMER JB, FARRAR DG, WILSON J: The effect of indomethacin on the tracheal smooth muscle of the guinea-pig. Br J Pharmacol 46: 536P-537P, 1972.

GELFAND EW: Role of histamine in the pathophysiology of asthma: immunomodulatory and anti-inflammatory activities of H1-receptor antagonists. Am J Med 113 (Suppl 9A): 2S-7S, 2002.

CHABY R, GARCIA-VERDUGO I, ESPINASSOUS Q, AUGUSTO LA: Interactions between LPS and lung surfactant proteins. J Endotoxin Res 11: 181-185, 2005.

JOHNSTON RA, VAN SCOTT MR, KOMMINENI C, MILLECCHIA LL, DORTCH-CARNES J, FEDAN JS: Hyperosmolar solution effects in guinea pig airways. IV. Lipopolysaccharide-induced alterations in airway reactivity and epithelial bioelectric responses to methacholine and hyperosmolarity. J Pharmacol Exp Ther 308: 37-46, 2004.

JONES TR, LABELLE M, BELLEY M, CHAMPION E, CHARETTE L, EVANS J, FORD-HUTCHINSON AW, GAUTHIER JY, LORD A, MASSON P: Pharmacology of montelukast sodium (Singulair), a potent and selective leukotriene D4 receptor antagonist. Can J Physiol Pharmacol 73: 191-201, 1995. 
KOETZLER R, SAIFEDDINE M, YU Z, SCHÜRCH FS, HOLLENBERG MD, GREEN FH: Surfactant as an airway smooth muscle relaxant. Am J Respir Cell Mol Biol 34: 609-615, 2006.

KOLOMAZNIK M, ZILA I, KOPINCOVA J, MOKRA D, CALKOVSKA A: Changes in lung surfactant proteins in rats with lipopolysaccharide-induced fever. Physiol Res 63 (Suppl 4): S619-S628, 2014.

KOLOMAZNIK M, NOVA Z, CALKOVSKA A: Pulmonary surfactant and bacterial lipopolysaccharide: the interaction and its functional consequences. Physiol Res 66 (Suppl 2): S147-S157, 2017.

KOLOMAZNIK M, LISKAYOVA G, KANJAKOVA N, HUBCIK L, UHRIKOVA D, CALKOVSKA A: The perturbation of pulmonary surfactant by bacterial lipopolysaccharide and its reversal by polymyxin B: function and structure. Int J Mol Sci 19: pii: E1964, 2018.

KOPINCOVÁ J, MOKRÁ D, MIKOLKA P, KOLOMAZNÍK M, ČALKOVSKÁ A: N-acetylcysteine advancement of surfactant therapy in experimental meconium aspiration syndrome: possible mechanisms. Physiol Res 63 (Suppl 4): S629-S642, 2014.

LEONENKO Z, RODENSTEIN M, DÖHNER J, ENG LM, AMREIN M: Electrical surface potential of pulmonary surfactant. Langmuir 22: 10135-10139, 2006.

LIU M, WANG L, LI E, ENHORNING G: Pulmonary surfactant given prophylactically alleviates an asthma attack in guinea-pigs. Clin Exp Allergy 26: 270-275, 1996.

LOPEZ-RODRIGUEZ E, PÉREZ-GIL J: Structure-function relationships in pulmonary surfactant membranes: from biophysics to therapy. Biochim Biophys Acta 1838: 1568-1585, 2014.

MAREK W, OZYURT M, POTTHAST J, MENSING T: Endotoxin-induced airway hyperresponsiveness in rabbits: contribution of neuropeptides. J Physiol Pharmacol 59 (Suppl 6): 421-432, 2008.

MARSHALL I: Characterization and distribution of histamine H1- and H2-receptors in precapillary vessels. J Cardiovasc Pharmacol 6 (Suppl 4): S587-S597, 1984.

MOKRA D, CALKOVSKA A: Experimental models of acute lung injury in the newborns. Physiol Res 66 (Suppl 2): S187-S201, 2017.

MOKRY J, MOKRA D, ANTOSOVA M, BULIKOVA J, CALKOVSKA A, NOSALOVA G: Dexamethasone alleviates meconium-induced airway hyperresponsiveness and lung inflammation in rabbits. Pediatr Pulmonol 41: 55-60, 2006.

NOGRADY SG, BEVAN C: H2 receptor blockade and bronchial hyperreactivity to histamine in asthma. Thorax 36: 268-271, 1981.

NOVA Z, SKOVIEROVA H, CALKOVSKA A: Alveolar-capillary membrane-related pulmonary cells as a target in endotoxin-induced acute lung injury. Int J Mol Sci 20: pii: E831, 2019.

PARSONS ME, GANELLIN CR: Histamine and its receptors. Br J Pharmacol 147 (Suppl 1): S127-S135, 2006.

PETERS-GOLDEN M, CANETTI C, MANCUSO P, COFFEY MJ: Leukotrienes: underappreciated mediators of innate immune responses. J Immunol 174: 589-594, 2005.

PRIYANKA K, SATHALI AA: Preparation and evaluation of montelukast sodium loaded solid lipid nanoparticles. J Young Pharm 4: 129-137, 2012.

RAETZ CR, ULEVITCH RJ, WRIGHT SD, SIBLEY CH, DING A, NATHAN CF: Gram-negative endotoxin: an extraordinary lipid with profound effects on eukaryotic signal transduction. FASEB J 5: 2652-2660, 1991.

RUAN CHH, DIXON RAF, WILLERSON JT, RUAN KH: Prostacyclin therapy for pulmonary arterial hypertension. Tex Heart Inst J 37: 391-399, 2010.

SALVESEN B, STENVIK J, ROSSETTI C, SAUGSTAD OD, ESPEVIK T, MOLLNES TE: Meconium-induced release of cytokines is mediated by the TRL4/MD-2 complex in a CD14-dependent manner. Mol Immunol 47: 1226-1234, 2010.

SCOTT A, WELDON S, BUCHANAN PJ, SCHOCK B, ERNST RK, MCAULEY DF, TUNNEY MM, IRWIN CR, ELBORN JS, TAGGART CC: Evaluation of the ability of LL-37 to neutralise LPS in vitro and ex vivo. PLoS One 6: e26525, 2011.

SCHWARTZ DA, CHRIST WJ, KLEEBERGER SR, WOHLFORD-LENANE CL: Inhibition of LPS-induced airway hyperresponsiveness and airway inflammation by LPS antagonists. Am J Physiol Lung Cell Mol Physiol 280: L771-L778, 2001. 
VANE JR: Inhibition of prostaglandin synthesis as a mechanism of action for aspirin-like drugs. Nat New Biol 231: 232-235, 1971.

WEG VB, WALSH DT, FACCIOLI LH, WILIAMS TJ, FELDMANN M, NOURSHARGH S: LPS-induced 111In eosinophil accumulation in guinea-pig skin: evidence for a role for TNF- $\alpha$. Immunology 84: 36-40, 1995.

XIANG M, FAN J, FAN J: Association of Toll-like receptor signalling and reactive oxygen species: a potential therapeutic target for posttrauma acute lung injury. Mediators Inflamm 2010: pii: 916425, 2010.

YAMAWAKI I, TAMAOKI J, KANEMURA T, HORII S, TAKIZAWA T: Effects of lipopolysaccharide from Pseudomonas aeruginosa on airway smooth muscle functions in guinea pigs. Respiration 57: 268-274, 1990.

ZHOU HS, LI M, SUI BD, WEI L, HOU R, CHEN WS, LI Q, BI SH, ZHANG JZ, YI DH: Lipopolysaccharide impairs permeability of pulmonary microvascular endothelial cells via Connexin40. Microvasc Res 115: 58-67, 2018. 